\title{
The role of construction materials in modern landscape design
}

\begin{abstract}
The article deals with the peculiarities of application, along with traditional, new building materials and products in the landscape design of the urban environment. The techniques and perspectives of their use in contemporary landscape design and compositions are highlighted and examples are given.
\end{abstract}

Keywords: landscape design, traditional and new building materials and products

\section{Introduction}

The main means of creation of landscape compositions is the harmonious combination of hydrographic, relief, plant and other natural and artificial elements, such as geoplastic, water devices, decorative coatings, small architectural forms and other elements of landscaping and arrangement of territories. The combination of natural and artificial components of the environment, in accordance with a certain artistic design into a holistic spatial composition, is a major task in the formation of objects of landscape design. Their aesthetic quality and efficiency of improving the urban environment largely depends on the material and technical means of its implementation, among which a significant role belongs to construction products and materials.

Problems of landscape design of the urban environment were covered in many scientific works and are in close connection with the general scientific programs and processes, which are united by the concepts of "Sustainable Development" [1-5]. Aspects of the implementation of the urban environment in the system of material entities and the introduction of architecture and design of modern building materials in recent years paid more and more attention by various authors, mostly material scientists [6-13]. At the same time, the problems of the effective use of certain building materials in the design of the architectural environment were not considered comprehensively.

The purpose of this article is to highlight the peculiarities of application, along with traditional, new innovative building materials in the modern landscape design.

\section{The main part}

According to the latest most informative publications and textbooks devoted to modern building materials [6-10], the classification of building materials is carried out on various features, including by origin, chemical composition, features of technology and purpose. By the features of the use of building materials and products during the formation of objects of landscape design of the urban environment and the peculiari- ties of their technology, it is possible to distinguish the following groups: natural stone materials; ceramic materials and products; materials and products from wood; metal materials; concrete and reinforced concrete; glass and other materials and products from mineral melts; polymer materials. Among them, it is possible to attribute the first four positions to the traditional conditionally, and the last to the innovation ones. Let's consider in a concise way the features and prospects of their use in landscape design.

Natural stone is widely used in the organization of landscape compositions. At the dawn of human civilization, the artistic elaboration of natural and artificial elements of the environment and landscape art objects, ranging from the Ancient World and the Middle Ages, the greatest embodiment got it in natural stone. Despite the use of other natural and synthetic materials in the new and modern history of architecture and landscape design, it is unique "taste" of color and texture of natural stone range provides special artistic and figurative characteristics to the environment of streets and parks, city squares and boulevards, parks and estates.

The main and most ambitious landscape art objects were and still are the palace and temple complexes, agoras and villas, various buildings of cultural, entertainment, commercial, and domestic purposes. The use of natural stone as bearing structural and finishing material for various facilities, buildings and systems is spread wide. As an example should be taken two outstanding examples of architectural and landscape ensembles - Alupka and Livadia Palaces in Crimea that appeared composite cores of similar terrain parks. The- 
se masterpieces of architecture and landscaping art are organically combined with the general design plan of external and internal environment of parks. A typical natural stone is used in almost all media of landscape design: ground plastic of relief, water arrangements, decorative surfaces, small architectural forms, elements of decorative art and beautification. Natural stone is unsurpassed material for the formation of ground plastic of landscape objects. Plastic forms of earth and rock gardens can be used in the formation of various and rock gaic ons lim spaces, la hing a the surroundings that limit water bodics, divide them in certain are form the identification spadies, different diferest shapes, slopes, retaining walls, craters, canyons - carry out zoning areas and ant inages in che best way, create a comforGround plastic of I o valious functiona purpose (ill. 1). Ground plastic of landscape decisions of traditional and modern small gardens in the Chinese and Japanese styles is impossible without the use of natural stone in a variety of atistic and stylstic compositens. This is due to the fact that Far Eastern landscape art based on the reproduction of wildlife scaled in some way. Banks of natural and artificial ponds, rock gardens, different mounds and hills are arranged using natural stone. Many European parks is impossible without open and closed spaces, cascades and grottoes. In the application of various aquatic devices that enhance the imagery landscape compositions, natural stone is most indispensable material. To arrange decorative fountains and pools the use of the processed natural stone is more typical. For this purpose, you should choose a stone of beautiful shape, according to their purpose should serve as a local accent in the space environment of the park. Natural stones are fixed with mortar when making thresholds. The formation of various picturesque streams, waterfalls, cascades, streams of water, usually carried out by varying forms of stones and their installation. The type and nature of the coating, which is a necessary com ponent of forming the landscape compositions is of aesthetic pone. Therefore, in parks, value. The for a coating of iss in perks, stony paths with plants bethe stones. Pathways and countyards, watios can also be lined with natural stone. One of the options for quick placement of outdoor areas - patios, terraces, verandas - a ready-made kit, consisting of selecthick $2.55 .5 \mathrm{~cm}$, made of linom, $30 \times 30 \mathrm{~cm}$ to $90 \times 60$, thickness $2.5-3.5 \mathrm{~cm}$, made of limestone, sandstone, slate. Natural stone is used for the formation of diverse functionality and spatial characteristics of small architectural forms. The most common is the placement of decorative stone walls and pergolas, consisting of several stone arches connected by a wooden lattice.

Depending on the total plan the natural stone is used in the design of pavilions, benches and other elements of improvement, and for a variety of three-dimensional sculptures and monuments. The usage of, for example, marble or granite for sculptures and landscaping elements of parks is common for many prominent monuments of landscape and palace art in Europe.
Ceramic materials and products play an important role in creation of objects of landscape design. This most ancient artificial stone material, along with natural stone, was widely used in landscape art from the time of the Ancien World. Famous temples, palaces, worship and manor buildings and structures that are based on various variations and technology of ceramic materials, as well as other elements of landscape architecture and design, wide used in all stages of historical development used in all stages of his

Pottery significant advantage compared to natural stone is more simplified capabilities of tran stone is more sinplified capabilies cranction dardization and small size of items. These circumstances are important for those regions where the deposits and mining of natural stone are missing. This material is also characterized in the exterior design with the ability to create integrated artistic and imaginative landscape and composite solutions based on respect for stylistic unity of the building deve lopment ensemble and landscaping through the use of modular sizes of ceramic products. For example, the use of ceramic facing brick in the decoration of buildings and small architectural forms in the regeneration of the surrounding area was an important means of aesthetic subject-spatial compositions both historically and in modern practice of the formation of urban environment. The experience of development and comprehensive improvement of Khreschatyk Street in the city of Kyiv is worth the special attention, as its urban planning and landscape composition is the outsanding global model of construction and design of object-spatial environment.

Plastic possibilities of ceramic products provide possibing of ceramic products provide int posting ex of ceramic products proand education activities and the and educational activites and theatre performances. The use of bricks, ceramic tiles and other ceramic products for staircase is common enough and is an important functiona element of relief processing. While making design the landscape designer determine not only the location of the stairs in stric accordance with the direction and intensity of pedestrian traffic, but thoroughly develops the form of steps, the rhythm, the number of marches, perhaps alternating with ramps an a small playground. Decorative properties of ceramic products, such as colour, shape, size of elements, and figure of surface are essential in creating a harmonious landscape composition. And compared to natural stone, $\mathrm{ce}$

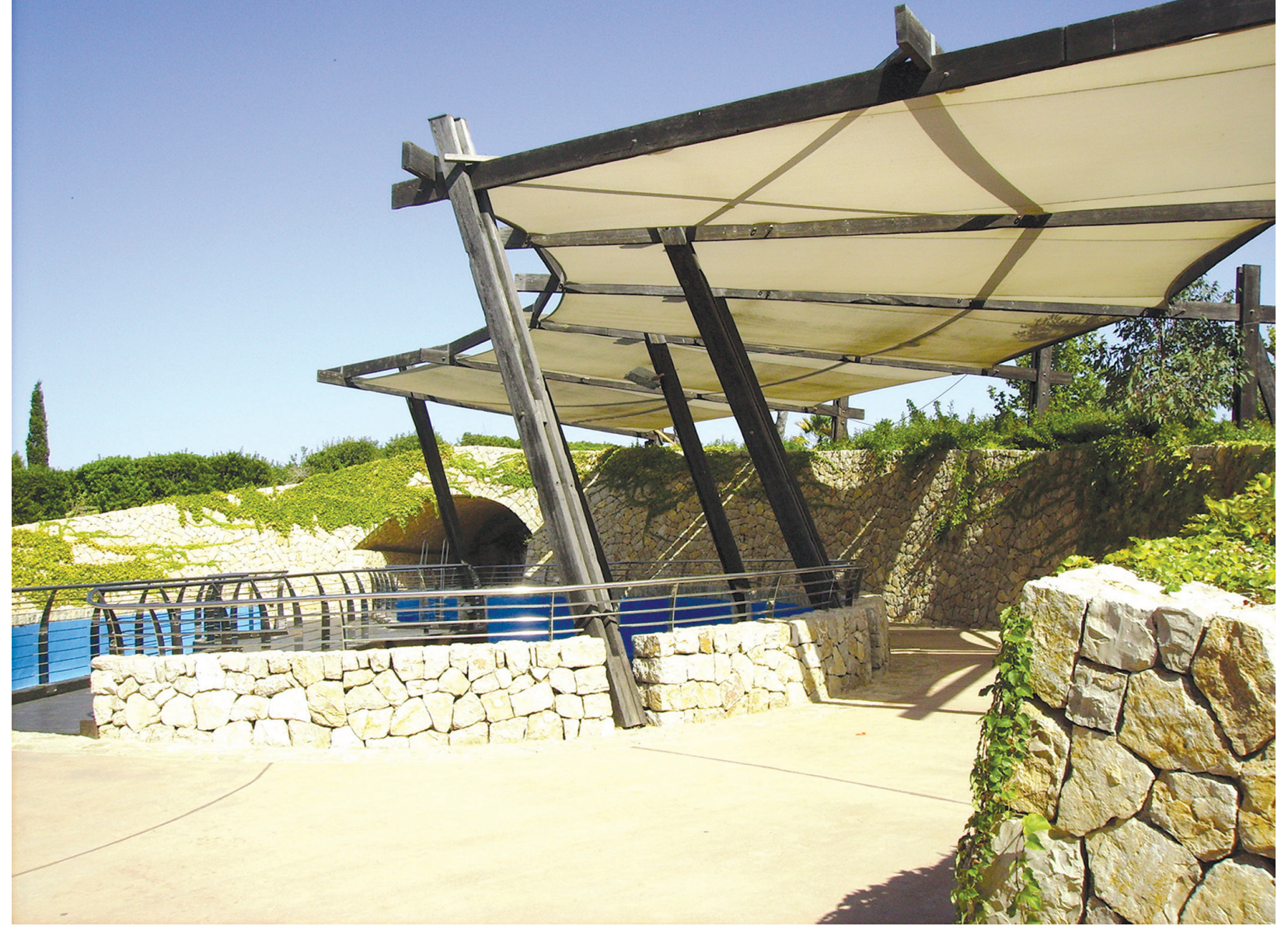

ill. 1. Natural stone and wood in the recreational area of Mallorca. Photo V. Abyzov

ramic materials are more common in regular style landscape environment with geometric grid plan and straight road terracing and clear contours of water objects. The ceramic bricks have got widespread use in the shaping of small architectura forms as structural and decorative material. They are used for bearings of benches, development of decorative walls, pergolas, pavilions, sunshades, as well as for various small business services. In combination with bricks, tiles are also often used to cover roofs and creating various canopies. The often used to cover use of varion the achieving of high aesthetic param glazed tiles ding cor ling color, she are und exten shape and for texs of These ceramic products are s, walls and carpet tracks [11]

we as natural stone, are widely spread building materials, that were used by mankind since antiquity. The availability of wood in forest rich areas and its undeniable advantages, such as certain strength and lightness, the ability to keep warmth in winter and coolness in summer contributed to the common use of this material in buildings and strutures of different purpose.

History of landscape art is full of examples of the outstanding religious buildings, wooden houses, pavilions, gazebos, where wood is an excellent construction, finishing and decorative material. The most interesting examples are unique Slavic churches and Far East (Chinese, Japanese, Indochina) Buddhist temples and pagodas, where handy color processing discovers the tectonic features of the wooden structures and materials. The best architectural monuments of such artistic works are included in the UNESCO World Heritage list, and among the objects in this list there is the joint Ukrainian-Polish nomination for the Carpathian wooden churches.

Despite some constructive advantages of stone and concrete materials in the processing of the land surface, the use of wood in the form of horizontal and vertical structural elements provides good artistically-figured design (ill 1). At the same time, some types of wood, such as oak, hornbeam, beech can be used for a long period of time as bearing e une effects of ai and water. The unique ubathe suburba landscapes of the St. Peters and Am Ansterdam, Zhou Zhuang, and others are ies of the cres of above. Modern technoloen en glued constructions of different contours provide new opportunities for the creation of various types and forms of landscape objects. All this is manifested in the implementation of Altis is manifestedin the inplemer park scenes, benches and other small architecural forms, fences, sculptural compositions (ill.2a,b). 

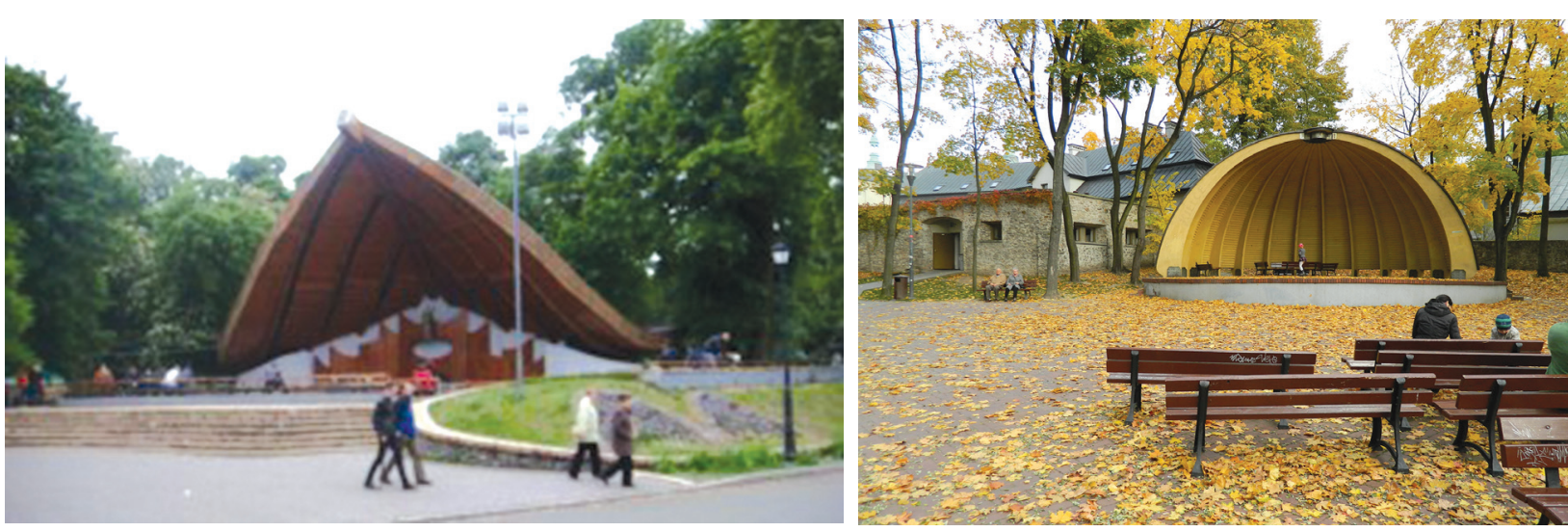

ill. 2a. Summer theaters in wooden structures. Kiev. Photo V. Abyzov
ili. 2b. Summer theaters in wooden structures. KKielce. Photo V . Abyzov

Metal materials and products are used for the engineering constructions in the form of girders, arches, trusses, frames, domes, frames, towers; as well as the light steel thin-walled quickly mounted structures; installation of roofs (copper, aluminum, zinc-titanium in the form of metal tile and profile decking), drain sewerage systems, staircases, pavilions, buildings, facades (using smooth, corrugated, structural sheets, panels, cassettes with aluminum and steel), small architectural forms, lighting, street furniture, fences, etc. If the metal has traditionally been used in residential and public buildings as the main load-bearing structures, then lately it is more common as a facing material in the form of a variety of texture and color sheet materials. Aluminum composite panels most widely used in buildings of cultural, entertainment and commercial purposes. In addition, interesting solutions of exhibition and trade pavilions, summer theatres and restaurants, engineering constructions and bridge crossings are known, where the metal supporting structures at the same time work as active compositionally structure-creating decorative elements (ill 3). At the same time for such items of geoplastics as terraces, ramps, stais, bridges, etc as the protective mas terraces met products are used. Their color, the natur of the prometal products are used. Their color the nare of the procossion at foring, which can be the conneting aestic forging, which can be whe connecting aesthetic and artistic tool for a vaicty of objects and elements of landscape design: fencing, small architectural forms and street furniture, fences, gates, gratings, etc. Practically an indispensable material is metal in the shaping of various lamps, fixtures and other lighting elements of internal and external environment. The strength and durability of metal materials are successfully used in the structures of visual communications - advertising boards, stands, showcases, etc. When creating landscape compositions using small architectural forms it is very important to ensure the unity of the stylistic solutions, and in many ways this may contribute to the application of the plastic properties of metal products and artistic forging. Along with the traditional bronze for the sculptures of landscape design other metal materials are used also - alloys of non-ferrous metals - copper, aluminum, brass, titanium, that have high corrosion resistance and ductility. The new technical and operational quality of metal materials is opening the further perspectives and creative possibilities of their use in landscap design

The use of metal products in small architecturscale structures and devices for seasonal and year-round use, designed to serve the population in the urban and natural environment. They can be stationary or transforming and have, as a rule, utilitarian, artistic, and decorative purpose, or only decorative. The utilitarian buildings typically include gazebos, public transport stops, trade and information kiosks, automatic trading devices, shading structures, lights, benches and other urban furniture $[6,9,10]$.

Constructional advantages of concrete are known since the times of ancient Rome, where the widespread distribution of this unique building material was of revolutionary impormortar mixures for the brick valts gave to mankind the new form - the archi and its spatial derivative - the dome. The next defining moment in architecture and design defining moment in architecture and design there was a combination of the steel reinforcement with the concrete and widespread use of reinforced concrete in the first half of the twentieth century. Later the use of concrete and reinforced concrete came into landscap design. Structural and decorative features of these materials were reflected in the building of residential, public and industrial use, as well as in the infrastructure of the cities in the derground crossings, stadiums, etc.

Concrete and reinforced concrete allow to create flexible forms; they are the most costal forms deserves the special attention - smal tance to the wold of architecture. The use of construction of bridges, aboveground and un-

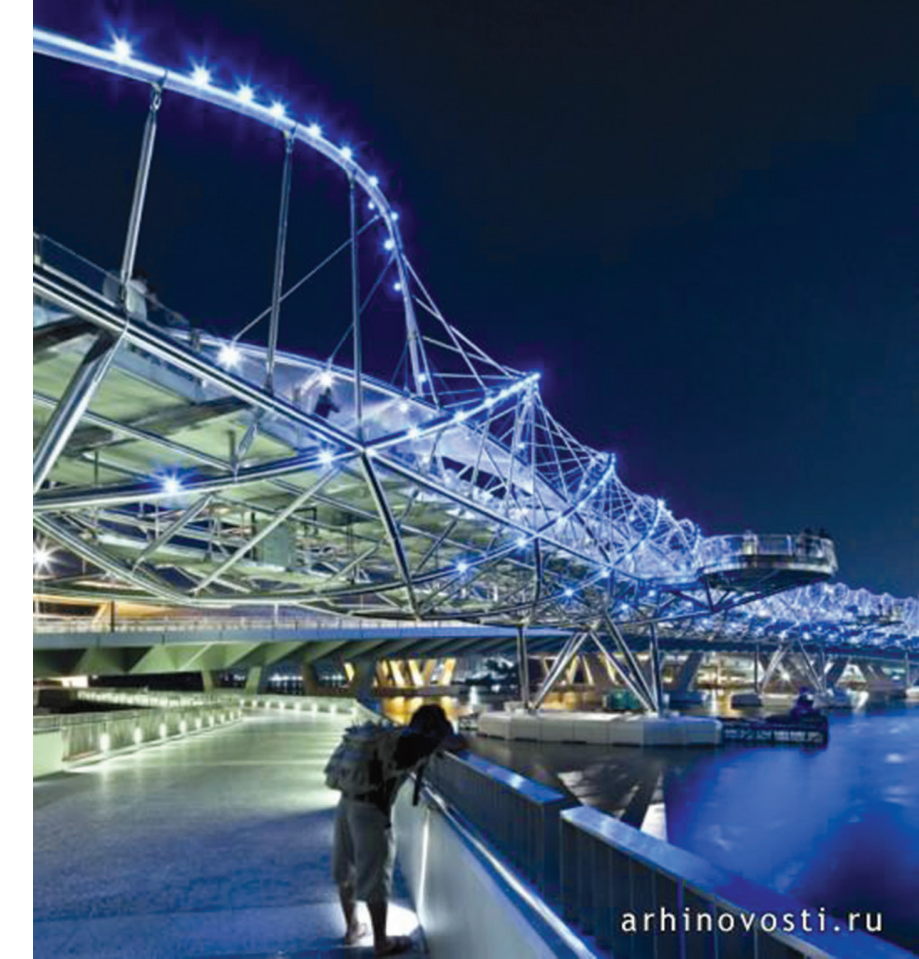

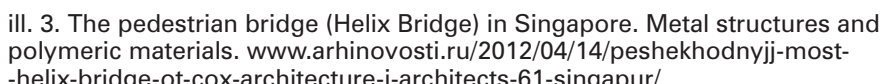

-effective materials for arrangement of ground surfaces and slopes, retaining walls, stairs, ramps, terraces, hills, etc. A the same time these materials obtained a successful use in the simulation of natural landforms, embedding of various enterprises of domestic and cultural-entertaining characte into relief. The widespread distribution of concrete and reinforced concrete have in the arrangement of various aquatic zones in landscape design (waterfalls, cascades, etc.). The latter often have interesting decorative characteristics of sculpatter often have interesting decorative characteristics of sculrtu forming the these materials are used either as structuas, for cost to inplement design procts moder techos high cost to imple low to creassible (iil. 4). The mos com the compositions of natural materials ced . The most common is the use of concrete and reinforced concrete for construction of open and closed decorative and swimming pools.

The main type of decorative coatings of artificial materials in landscape design is a variety of artificial stones from concrete with different and pigments. Easy handling, they have great multi-variant use by size, texture, and color. Overlaps of concrete plates are characterized by diversity and affordab lity. Shaped paving elements (SPE) have recently most widely spread as road surfaces in landscape design. They differ in a variety of shapes and colors, that expands the desig possibilities when implementing new architectural solutions. Despite the widespread use of SPE, the concrete sidewalk plates are still used for installation in different economic zones and areas. They are made of heavy and fine-grained concrete and used for installation of prefabricated coverings of sidewalks, pedestrian zones, garden-park and pedestrian paths, public transportation and petrol stations [8]

The widespread use of concrete and reinforced concrete have gained in the creation of small architectural forms - the main artificial means of landscape design. The use of concrete and reinforced concrete for the of concrete and reinforced concrete for the

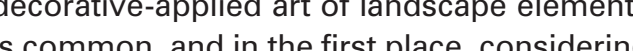
the high planticity of these mlace, considering

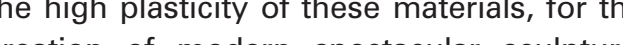
cculptura crempition consiona decorative sculptures, their constructive, color and composition solution depends on how they will be placed in combintion with vegetaton, reller, pedestrian Detc

During the centuries-old history of the architecture and design, glass received the most widespread and large-scale implementatio as constructive, and rather constructive-proective and architectural-decorative material. In addition to the traditional use of glass in a variety of buildings and structures, in the landscape design it also was skillfully used in compositions of greenhouses and winter gardens of palace complexes since the Renaissance.

Nowadays, due to the rapid development of new technologies the glass usage acquires new possibilities. Along with traditiona protective functions of the geoplastic tools, such as the establishment of microclimates, protection against dust, wind, and sun glas preducts aganst dust, wind, and sun, glass pronity spatially orstrength and new static and dynacteristics of of glass allow its usage whic arrangitities

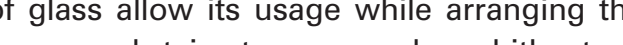
The function which play an importion in which play an important role in the composition of space. The creation of these important compositional elements of the landscape of transparent glass gives new feeling and aes thetic impression $[9,11,13]$. Considering the fact that glass can perform the function of bearing horizontal structures, it is also possible to organize bridge transitions and overlays of various form of runs. Transparent glass floorings can perform a purely decorative function, but also can have a functional purpose. As an interesting example we may call the clear glass ceiling over archaeological excavations of ceramic soldiers in the first and the ancient capital of China - X'an. The museum 
ges, circus tents, summer cafes, tennis courts, sports grounds. The advantages of such structures are the rapid erection and installation on any territory, the ease of installation and minimum costs. High physical-mechanical and decorative properties of polymeric materials allow to effectively use them to arrange elements of monumental-decorative art and sculptural compositions of landscape design. The wide range of color and texture processing of organic concrete that allows to create a variety of aesthetic and attractive composition, contributes to this also (ill. 6).

\section{Conclusion}

Modern traditional and latest innovative building materials such as natural stone materials, ceramic materials and products, materials and products from wood, metal materials, concrete and reinforced concrete, glass and other materials and products from mineral melts, polymer materials play an important role in contemporary landscape design and are the main means of creating harmonious and expressive landscape compositions and formations.

The set, combinations and general artistic image of the use of building materials in the objects of landscape design should be determined by the urban planning, functional, and lay out features of the designing areas in conjunction with the environmental compositional and spatial design. With all the diversity of their possible artistic and decorative solutions, an essential condition is the achievement of the stylistic unity of the overall composition of landscape design.

\section{BIBLIOGRAPHY}

[1] Vadym Abyzov. Modern Conditions and the Impacts of the Creation of Architectural Environment. Materials Science \& Engineering - IOP (Volume 245) World Multidisciplinary Civil Engineering-Architecture-Urban Planning Symposium - WMCAUS 12-16 June 2017, Prague, Czech Republic Published online: 4 November, Bristol, 2017

[2] Vadym Abyzov. Typological, Systematic and Structural Principles of Forming a Recreational Environment. Housing Environment, - Cracow University of Technology, 16/2016

[3] Millennium Ecosystem Assessment. 2005. Ecosystems and human well-being: Synthesis. Island Press, Washington, DC. Accessed March 2013

[4] de Botton A. The Architecture of Happiness. Penguin UK, 2007

[5] Lucian Kamionka. Projektowwanie zrównowazone - próby okreslenia parameterów. Projektowwanie zrownowazone jako paradygmat kszaltowania przestrzeni w XXI wieku. Monografia, Architektura 3, Politechnika Świętokrzyska, Kielce, 2016

[6] M. L. Gambhir, Neha Jamwal. Building Materials Products, Properties and Systems. Wyd. Tata McGraw-Hill, 2011

[7] Marco Bussagli. Architektura. Style, techniki, materiały, budowle, twórcy. (Capire L'Architettura). Wyd. Świat książki, 20072.

[8] Krivenko P.V., Pushkareva K.K., Baranovsky V.B., Kochevykh M.O. etc. Building Material Science. Textbook. Kyiv: "Lira-K", 2012

[9] Pushkareva K.K., Kochevich M.O., Gonchar, O.A., Bondarenko O.P. Material Science. Textbook. Kyiv: "Lira-K", 2012.

[10] Budownictwo ogólne, tom 1. Materiały i wyroby budowlane. Praca zbiorowa pod kierunkiem B. Stefańczyka; wyd. Arkady, 2007

[11] Ewa Osiecka. Materiały budowlane. Kamień - ceramika - szkło. Wyd. Politechnika Warszawska, 2003

[12] Vadym Abyzov. Theory of Architecture-\&-Construction Systems Development. Monograph. Kyiv: KNUKiM, 2009

[13] Otcheskih K.A. "Clever Glass" in Modern Architecture. Young Scientist. 2013, No 4.

URL https://moluch.ru/archive/51/6513/ 